\title{
Unveiling the Potential of Transition Metal Complexes for Medicine: Translational in situ Activation of Metal-based Drugs from Bench to in vivo Applications
}

\author{
Maria J. S. A. Silva, ${ }^{[a, b]}$ Pedro M. P. Gois ${ }^{[b] *}$, and Gilles Gasser ${ }^{[a]^{*}}$ \\ [a] M. J. S. A. Silva, Dr. G. Gasser \\ Chimie ParisTech, PSL University, CNRS, Institute of Chemistry for Life and Health Sciences, Laboratory for Inorganic Chemical Biology, F-75005 Paris, \\ France \\ E-mail: gilles.gasser@chimieparistech.psl.eu \\ [b] M. J. S. A. Silva, Dr. P. M. P. Gois, \\ Research Institute for Medicines (iMed.ULisboa), Faculty of Pharmacy, Universidade de Lisboa, Lisbon, Portugal. \\ E-mail: pedrogois@ff.ulisboa.pt
}

\begin{abstract}
The development of metal-based anticancer drugs has been hampered, among other reasons, by their lack of selectivity for cancer cells. In a recent article, Zou and co-workers presented the successful intracellular activation of organogold(I) complexes for potential cancer treatment through $\mathrm{Pd}(\mathrm{II})$-mediated transmetallation, overcoming some off-target activity of novel gold-based drugs. This unique strategy builds the perfect bridge between metallodrugs usage and bioorthogonal intracellular catalysis for more advanced and selective therapies. Such an approach will hopefully pave the way for forthcoming studies in medicinal inorganic chemistry.
\end{abstract}

The emergent use of transition metal (TM) complexes in clinical practice for the detection or treatment of different diseases has been impressive over the last years. ${ }^{[1]}$ Besides the most renowned three $\mathrm{Pt}(\mathrm{II})$-based drugs that are used worldwide, $\mathrm{Pd}(\mathrm{II}), \mathrm{Ru}(\mathrm{II})$ and (III) complexes have been showing promising results as anticancer, antimicrobial, antiparasitic and antiviral agents over the past decades. Apart from metallodrugs with intrinsic biological activity, TM have also been explored for intracellular catalysis since Sharpless and Meldal groups' groundbreaking discovery of biocompatible $\mathrm{Cu}(\mathrm{I})$-catalysed azide-alkyne cycloaddition (CuAAC). ${ }^{[2]}$ Intracellular catalysis mediated by $\mathrm{Pd}(0)$ and (II), $\mathrm{Ru}(\mathrm{II})$ and $\mathrm{Fe}(\mathrm{II})$ has become an invaluable tool for photodynamic therapy, prodrug activation, in situ drug and probe synthesis or uncaging and peptide labeling in living cells. ${ }^{[3]}$ Such highly sophisticated technologies promote bioorthogonal reactions by means of catalysts that only react with a defined pair, while being innocuous towards all other surrounding entities. This concept is extremely demanding in complex environments such as living cells.

Encouraged by antirheumatic agent Auranofin repurposing for cancer treatment, gold complexes are currently emerging as a novel class of promising anticancer metal-based drugs. ${ }^{[4]}$ Notably, oxygen and moisture tolerant $\mathrm{Au}(\mathrm{I})$ species present particular reactivities that allow the exploitation of alternative pathways for biocatalysis and multitargeted approaches in biocompatible environments. ${ }^{[5]}$ However, the high thiophilicity of $\mathrm{Au}(\mathrm{I})$ has been one of the major concerns of such complexes, which can undergo ligand exchange with ubiquitous thiolates in different biological media and consequently give rise to significant undesired side-effects. To address this issue, new methodologies have been developed to stabilize the metal center by using ligands with strong electron donating properties. Phosphines, alkynes and $\mathrm{N}$-heterocyclic carbenes (NHC) are the most common examples of strong $\sigma$-donors to prepare these stabilized $\mathrm{Au}(\mathrm{I})$ complexes without compromising their bioactivity. ${ }^{[6]}$ In particular, the great ability to tune the electronic and steric properties of $\mathrm{NHC}$ structure has rendered NHCtransition metal complexes significant improvements for catalysis and medical applications, including the development of new anticancer agents. ${ }^{[7]}$

Very recently, another appealing strategy has been described by Zou and co-workers for the controlled, bioorthogonal in situ activation of stable $\mathrm{Au}(\mathrm{I})$ complexes. This concept resulted in bioactive species with decreased off-target activity and improved selectivity. ${ }^{[8]}$ More specifically, the authors showed effective transmetallation of stable $\mathrm{NHC}$-Au(I)-alkyne complexes with non-toxic $\mathrm{Pd}(\mathrm{II})$ catalysts that resulted in $\mathrm{Au}(\mathrm{I})$ complexes with acquired anticancer activity. The preliminary results showed consistent activation of the $\mathrm{Au}(\mathrm{I})$ complexes not only in physiological-like conditions but also in more challenging environments such as living cancer cells. These observations clearly support the inertness of the dual-catalytic system towards significant amounts of thiols and proved its suitability for further in vitro and in vivo studies. Furthermore, as the $\mathrm{Au}(\mathrm{I})$ activation is $\mathrm{Pd}$ (II) transmetallation-dependent, installation of RGD peptide motif as targeting unit on the $\mathrm{Pd}(\mathrm{II})$ catalyst enhanced the specific activation of the described $\mathrm{Au}(\mathrm{l})$ complexes in a highly controlled fashion. Remarkably, instead of traditional direct labelling of organogold(I) complex, different Pd(II) accumulation on integrinoverexpressing cancer cells versus normal cells triggered the selective activation of organogold(I) complexes in cancer cells. However, the L-02 cells used as a normal cell line were recently revised by the International Cell Line Authentication Committee (ICLAC) to be cervical adenocarcinoma cells with HeLa cells as contaminating cell line. ${ }^{[9]}$ For this reason, additional toxicity studies should be conducted using other viable healthy cell lines in the future to further confirm the selectivity for cancer cells over normal cells. Nevertheless, the authors went even a step further by undertaking in vivo assays. A remarkable efficacy on the orthogonal activation of gold complexes, which halted the tumoral angiogenesis process in the zebrafish model, was unveiled. 


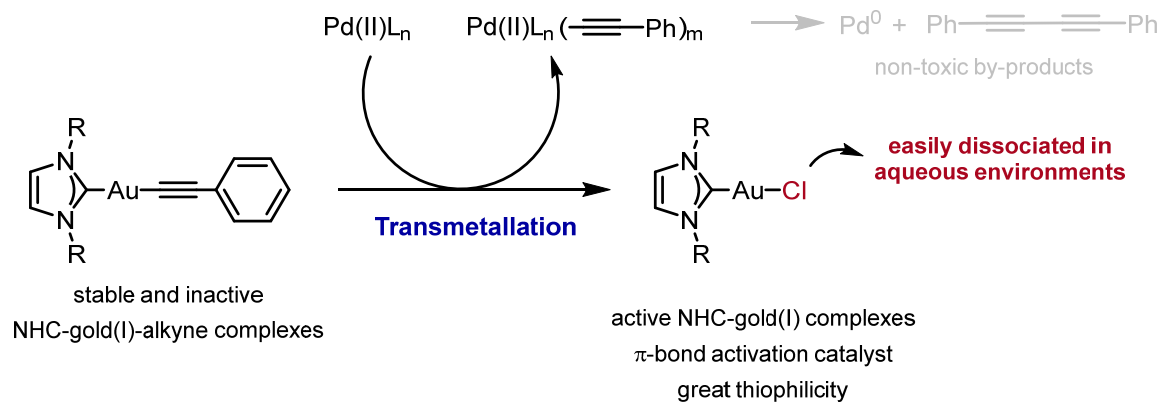

Figure 1 - Transmetallation of stable $\mathrm{NHC}-\mathrm{Au}(\mathrm{I})$-alkyne complexes with $\mathrm{Pd}(\mathrm{II})$ catalysts to provide in situ activated $\mathrm{Au}(\mathrm{I})$-chlorine complexes with anticancer properties.

In this article, we would like to emphasize the versatility of this elegant methodology by highlighting other possible course of actions that could be envisioned as potential targets and applications.

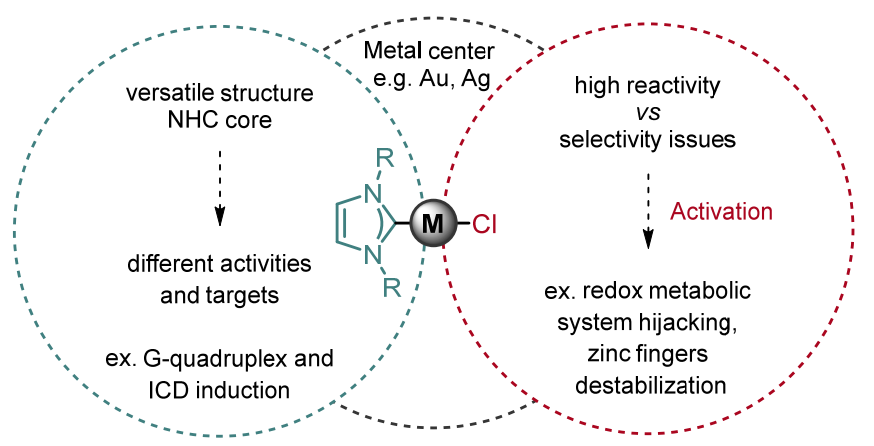

Figure 2 - Versality and activity potential of activated $\mathrm{NHC}-\mathrm{Au}(\mathrm{I})$ complexes.

First, beyond the inhibition of both isoforms of thioredoxin reductase (TrxR), which have been established as the primary targets for $\mathrm{Au}(\mathrm{I})$ complexes' mode of action, the specific activation of gold complexes could pave the way to exploit additional targets. Besides TrxR, there are other known thiolatedependent enzymes, namely human glutathione reductase (hGR), glutathione peroxidase (GpX), glutathione-S-transferases (GSTs) and cysteine protease. ${ }^{[10]}$ Building a multitarget metallodrug that could irreversibly disrupt a large part of the redox-active enzyme network would ultimately prevent the occurrence of acquired resistance mechanisms. Furthermore, redox metabolism plays crucial roles not only in cancer but also in parasitic and microbial diseases. Thus, the design of specific activation strategies in pathogenic organisms would be a valuable strategy to advance the treatment of worldwide infectious diseases.

The diversity of activities of organogold $(\mathrm{I})$ complexes is highly dependent on the ligand structures. This has been widely explored in very recent works. Schobert and co-workers showed how NHC structural changes are determinant for distinct intracellular accumulation and distribution, resulting in diverse mode of actions and anticancer activities. ${ }^{[11]}$ The Casini group applied purine-based NHC ligands for G-quadruplex interactions. ${ }^{[12]}$ The Ott group described the multivalency of potential targets of xanthine-derived alkynylgold $(I)$ complexes, including aneuploidy induction for cancer cell death, anti- metastatic and vascular disruption effects. ${ }^{[13]}$ Enhancement of oxidative stress induction has been explored by the same group using $\mathrm{NHC}$ ligands equipped with ferrocenyl moieties and also by Wei and co-workers by decorating the ligand with a naphthoquinone motif with subsequent promotion of immunogenic cell death. ${ }^{[14]}$ According to this latter work, the redox imbalance experienced by the treated cells triggered an effective anticancer immune response through the generation of death signals known as damage-associated molecular patterns (DAMPs). Furthermore, the role of gold-based drugs in anticancer immunity has been thoroughly reviewed, underlining the potential of gold complexes to hamper diverse immune escape mechanisms build-up by tumor cells. ${ }^{[15]}$

Another interesting target for in situ gold complexes activation would be the formation of gold fingers that destabilize the precursor zinc fingers conformation. In this context, $\mathrm{Au}(\mathrm{I})$ and $\mathrm{Au}$ (III) complexes equipped with labile ligands facilitate zinc(II) ion ejection to afford stable adducts with a distorted secondary structure. In theory, this could be easily promoted by $\mathrm{Pd}(\mathrm{II})$ transmetallation to afford a labile chlorine coordinate. The loss of the prerequisite protein shape resultant upon metal exchange showed a great impact on the activity of zinc finger proteins such as Sp1 and TFIIIA transcription factors but also in the nucleocapsid protein HIVNCp7 zinc finger, which is crucial for RNA interaction and viral replication, as studied by Farrell group. ${ }^{[16]}$

Apart from stable $A u(I)$ complexes with $\sigma$-bonding donors, metallo-prodrugs containing other TM could be tested for the effective transmetallation with $\mathrm{Pd}(\mathrm{II})$ and biocatalysis activation. For instance, as for $\mathrm{Au}(\mathrm{I})$ complexes, the design of robust organosilver(I) compounds is also prized to avoid off-target toxicity. Toxic effects of silver complexes are highly dependent on the strength of ligand coordination that keeps silver ions unreactive until they reach the desired target. According to Mármol et al.'s latest results of $\mathrm{Ag}(\mathrm{I})$ 2-anilinopyridine-based heterocycle complexes, ${ }^{[17]}$ these new metallodrugs showed enhanced stability and offered alternative mechanisms of action than their $\mathrm{Au}(\mathrm{I})$ counterparts. The selective and controlled activation of such $\mathrm{Ag}(\mathrm{I})$ complexes mediated by $\mathrm{Pd}(\mathrm{II})$ could also be valid and newsworthy trial. Moreover, it would be appealing to study the transmetallation system for $\mathrm{Au}(\mathrm{I})$ activation compatibility with other metallodrugs with acknowledged activity such as cisplatin. The activated $A u(I)$ species potential disruption of GSTP1-1 enzymatic activity would hinder the inactivation of cisplatin by GSH conjugation. ${ }^{[18]}$ This is an example of a natural resistance mechanism to cisplatin that could be easily tackled by 
in situ activated $\mathrm{Au}(\mathrm{I})$ complexes, extending the potential of this highly selective approach.

This safer and highly controlled system developed by the Zou group is another successful example that reinforces the great potential of TM catalysis toolbox for in vivo studies. ${ }^{[19]}$ Hopefully, this will encourage the translation of such thriving endeavors to be applied in clinical practice in the near future as more advanced and targeted therapies.

\section{Acknowledgements}

The authors acknowledge the financial support from Fundação para a Ciência e a Tecnologia, Ministério da Ciência e da Tecnologia, Portugal (SFRH/BD/132710/2017, iMed.ULisboa UIDB/04138/2020 and UIDP/04138/2020; PTDC/QUIQOR/29967/2017); LISBOA-01-0145-FEDER-029967. This work was also financially supported by an ERC Consolidator Grant PhotoMedMet to G.G. (GA 681679), has received support under the program "Investissements d' Avenir" launched by the French Government and implemented by the ANR with the reference ANR-10-IDEX-0001-02 PSL (G.G.).

Keywords: anticancer drugs• intracellular catalysis • gold • palladium $\bullet$ transmetallation

\section{References}

[1] a) E. J. Anthony, E. M. Bolitho, H. E. Bridgewater, O. W. L. Carter, J. M. Donnelly, C. Imberti, E. C. Lant, F. Lermyte, R. J. Needham, M. Palau, P. J. Sadler, H. Shi, F.-X. Wang, W.-Y. Zhang, Z. Zhang, Chem. Sci 2020; b) E. Boros, P. J. Dyson, G. Gasser, Chem 2020, 6, 41-60; c) A. Johnson, J. Northcote-Smith, K. Suntharalingam, Trends Chem. 2020; d) J. Karges, ChemBioChem 2020, 21, 3044-3046.

[2] a) C. W. Tornøe, C. Christensen, M. Meldal, J. Org. Chem. 2002, 67, 3057-3064; b) V. V. Rostovtsev, L. G. Green, V. V. Fokin, K. B Sharpless, Angew. Chem. Int. Ed. 2002, 41, 2596-2599.

[3] a) R. C. Brewster, E. Klemencic, A. G. Jarvis, J. Inorg. Biochem. 2021, 215, 111317; b) J. Miguel-Ávila, M. Tomás-Gamasa, J. L. Mascareñas, Angew. Chem. Int. Ed. 2020, 59, 17628-17633; c) C. Vidal, M. TomásGamasa, A. Gutiérrez-González, J. L. Mascareñas, J. Am. Chem. Soc. 2019, 141, 5125-5129; d) C. Vidal, M. Tomás-Gamasa, P. Destito, F. López, J. L. Mascareñas, Nat. Commun. 2018, 9, 1913; e) M. MartínezCalvo, J. R. Couceiro, P. Destito, J. Rodríguez, J. Mosquera, J. L. Mascareñas, ACS Catal. 2018, 8, 6055-6061; f) M. Tomás-Gamasa, M Martínez-Calvo, J. R. Couceiro, J. L. Mascareñas, Nat. Commun. 2016, 7, 12538; g) M. I. Sánchez, C. Penas, M. E. Vázquez, J. L. Mascareñas Chem. Sci 2014, 5, 1901-1907; h) E. Indrigo, J. Clavadetscher, S. V. Chankeshwara, A. Megia-Fernandez, A. Lilienkampf, M. Bradley, ChemComm 2017, 53, 6712-6715; i) E. Indrigo, J. Clavadetscher, S. V. Chankeshwara, A. Lilienkampf, M. Bradley, ChemComm 2016, 52, 14212-14214; j) S. V. Chankeshwara, E. Indrigo, M. Bradley, Curr. Opin. Chem. Biol. 2014, 21, 128-135; k) J. T. Weiss, J. C. Dawson, K. G. Macleod, W. Rybski, C. Fraser, C. Torres-Sánchez, E. E. Patton, M. Bradley, N. O. Carragher, A. Unciti-Broceta, Nat. Commun. 2014, 5, 3277; I) A. Unciti-Broceta, E. M. V. Johansson, R. M. Yusop, R. M. Sánchez-Martín, M. Bradley, Nat. Protoc. 2012, 7, 1207-1218; m) R. M. Yusop, A. Unciti-Broceta, E. M. V. Johansson, R. M. Sánchez-Martín, M. Bradley, Nat. Chem. 2011, 3, 239-243; n) M. Yang, J. Li, P. R. Chen, Chem. Soc. Rev. 2014, 43, 6511-6526; o) C. D. Spicer, T. Triemer, B. G. Davis, J. Am. Chem. Soc. 2012, 134, 800-803; p) T. Völker, E. Meggers, Curr. Opin. Chem. Biol. 2015, 25, 48-54; q) P. K. Sasmal, C. N. Streu, E. Meggers, ChemComm 2013, 49, 1581-1587; r) P. K. Sasmal, S.
Carregal-Romero, A. A. Han, C. N. Streu, Z. Lin, K. Namikawa, S. L. Elliott, R. W. Köster, W. J. Parak, E. Meggers, ChemBioChem 2012, 13, 1116-1120; s) C. Streu, E. Meggers, Angew. Chem. Int. Ed. 2006, 45, 5645-5648.

[4] a) B. Bertrand, A. Casini, Dalton Trans. 2014, 43, 4209-4219; b) P. I. da Silva Maia, V. M. Deflon, U. Abram, Future Med. Chem. 2014, 6, 15151536; c) I. Ott, Coord. Chem. Rev. 2009, 253, 1670-1681; d) T. Zou, C T. Lum, C.-N. Lok, J.-J. Zhang, C.-M. Che, Chem. Soc. Rev. 2015, 44, 8786-8801; e) X. Zhang, K. Selvaraju, A. A. Saei, P. D'Arcy, R. A. Zubarev, E. S. J. Arnér, S. Linder, Biochimie 2019, 162, 46-54; f) C. Roder, M. J. Thomson, Drugs R D 2015, 15, 13-20.

[5] S. R. Thomas, A. Casini, Curr. Opin. Chem. Biol. 2020, 55, 103-110.

[6] Z. Yang, G. Jiang, Z. Xu, S. Zhao, W. Liu, Coord. Chem. Rev. 2020, 423, 213492.

[7] a) M. Mora, M. C. Gimeno, R. Visbal, Chem. Soc. Rev. 2019, 48, 447462; b) C. Romain, S. Bellemin-Laponnaz, S. Dagorne, Coord. Chem. Rev. 2020, 422, 213411.

[8] Y. Long, B. Cao, X. Xiong, A. S. C. Chan, R. W.-Y. Sun, T. Zou, Angew. Chem. Int. Ed. 2020, Accepted Author Manuscript. https://doi.org/10.1002/anie.202013366.

[9] Y. Huang, Y. Liu, C. Zheng, C. Shen, PloS one 2017, 12, e0170384.

[10] A. Giorgio, A. Merlino, Coord. Chem. Rev. 2020, 407, 213175.

[11] S. I. Bär, M. Gold, S. W. Schleser, T. Rehm, A. Bär, L. Köhler, L. L. Carnell, B. Biersack, R. Schobert, Chem. Eur. J. 2020, Accepted Author Manuscript. https://doi.org/10.1002/chem.202005451.

[12] S. M. Meier-Menches, B. Aikman, D. Döllerer, W. T. Klooster, S. J. Coles, N. Santi, L. Luk, A. Casini, R. Bonsignore, J. Inorg. Biochem. 2020, 202, 110844.

[13] J.-J. Zhang, M. A. Abu el Maaty, H. Hoffmeister, C. Schmidt, J. K. Muenzner, R. Schobert, S. Wölfl, I. Ott, Angew. Chem. Int. Ed. 2020, 59, $16795-16800$

[14] a) J. K. Muenzner, B. Biersack, A. Albrecht, T. Rehm, U. Lacher, W. Milius, A. Casini, J.-J. Zhang, I. Ott, V. Brabec, O. Stuchlikova, I. C. Andronache, L. Kaps, D. Schuppan, R. Schobert, Chem. Eur. J. 2016, 22, 18953-18962; b) S. Sen, S. Hufnagel, E. Y. Maier, I. Aguilar, J. Selvakumar, J. E. DeVore, V. M. Lynch, K. Arumugam, Z. Cui, J. L. Sessler, J. F. Arambula, J. Am. Chem. Soc. 2020

[15] a) S. Yue, M. Luo, H. Liu, S. Wei, Front. Chem. 2020, 8, 543-543; b) A. P. King, J. J. Wilson, Chem. Soc. Rev. 2020, 49, 8113-8136.

[16] C. Abbehausen, E. J. Peterson, R. E. F. de Paiva, P. P. Corbi, A. L. B. Formiga, Y. Qu, N. P. Farrell, Inorg. Chem. 2013, 52, 11280-11287.

[17] I. Mármol, S. Montanel-Perez, J. C. Royo, M. C. Gimeno, M. D. Villacampa, M. J. Rodríguez-Yoldi, E. Cerrada, Inorg. Chem. 2020.

[18] N. Allocati, M. Masulli, C. Di llio, L. Federici, Oncogenesis 2018, 7, 8.

[19] M. O. N. van de L'Isle, M. C. Ortega-Liebana, A. Unciti-Broceta, Curr. Opin. Chem. Biol. 2021, 61, 32-42. 


\section{Entry for the Table of Contents}

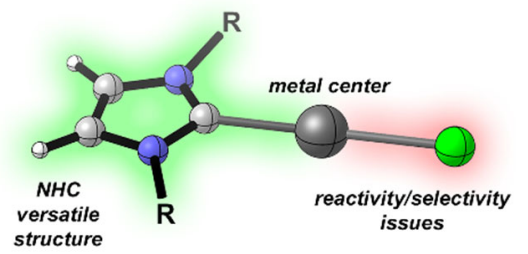

Novel metal-based drugs have recently been under the spotlight to treat diverse diseases. Fine control of off-targeted toxic effects was achieved by using a great variety of stabilized coordination ligands along with the use of different metal centers. In this article, we highlight the versatile, effective and valuable use of transition metals in medicine, namely for in situ activation of metal-based drugs.

Institute and/or researcher Twitter usernames: @GasserGroup @ChimieParisTech @psl_univ @MariaJSASilva @GoisLab @iMedULisboa 